\title{
ALEGORIA W „SKRZYDŁACH OŁTARZA”: HERLING-GRUDZIŃSKI, BENJAMIN, DE MAN
}

\author{
Słowa kluczowe: alegoria, symbol, ironia, Gustaw Herling-Grudziński, Walter Benjamin, Paul \\ de Man
}

Keywords: allegory, symbol, irony, Gustaw Herling-Grudziński, Walter Benjamin, Paul de Man

Problem, który zamierzam przeanalizować, ilustruje już motto dyptyku Herlinga: „I odemknąwszy jak księge skrzydta starego ottarza, ujrzat iż sa od wewnatrz dłutem misternie wyrobione $w$ drzewie: jedno przedstawiało Złożenie do Grobu, drugie Zmartwychwstanie. Z anonimowej opowieści weneckiej z XVI stulecia" . Kumuluje ono co najmniej trzy wątki, rozpoznane przez krytykę jako typowe dla twórczości Grudzińskiego: odniesienia do tradycji biblijnej i chrześcijańskiej ${ }^{2}$, rozbudowaną intertekstualność ${ }^{3}$ oraz intersemiotyczność, najbardziej typowo przejawiającą się w postaci ekfraz dzieł sztuki, zwłaszcza malarstwa ${ }^{4}$. Wszystkie te rozpoznania są trafne i będę je wykorzystywał w mojej interpretacji, co jednak interesuje mnie w szczególności, to właśnie splecenie ich w ciasny węzeł, jak w omawianym motcie - tak iż okazują się nie trzema odrębnymi mechanizmami, lecz raczej funkcjonalnie powiązanymi momentami jednej bardziej złożonej figury, co charakterystyczne - wzajemnie osłabiający mi swoje prymarne sensy: zmartwychwstanie jako typowy temat sztuk plastycznych nie jest

\footnotetext{
${ }^{1}$ Gustaw Herling-Grudziński, Skrzydła ołtarza (Kraków: Wydawnictwo Literackie, 2014), 5. Dalej numery stron w tekście głównym według tego wydania.

${ }^{2}$ E.g. Katarzyna Malinowska, Topika religijna w opowiadaniach Gustawa Herlinga-Grudzińskiego (Kraków: Universitas, 2006). Cf. Paweł Panas, Doświadczenie religijne w twórczości Gustawa Herlinga-Grudzińskiego (Lublin: Wydawnictwo KUL, 2012).

${ }^{3}$ E.g. Paweł Binek, „Intertekstualność jako kategoria formotwórcza opowiadań Gustawa Herlinga-Grudzińskiego", in Rozprawy Komisji Językowej XL, ed. Jan Miodek, Włodzimierz Wysoczański (Wrocław: Wydawnictwo WTN, 2013).

${ }^{4}$ E.g. Joanna Bielska-Krawczyk, Między widzialnym a niewidzialnym. Widzenie, kolor, świattocień i dzieła sztuki w twórczości Gustawa Herlinga-Grudzińskiego (Kraków: Universitas, 2004). Cf. „Cienie wielkich artystów”. Gustaw Herling-Grudziński i dawne malarstwo europejskie, ed. Agata Stankowska et al. (Poznań: Wydawnictwo PTPN, 2013).
} 
już wprost prawdą wiary, podobnie ekfraza zacytowana nie jest naocznym przedstawieniem dzieła faktycznie widzianego, tym bardziej, że typowy temat bez atrybucji utrudnia lub wręcz uniemożliwia identyfikację jego konkretnej realizacji, niczego też nie wiemy o ,anonimowej opowieści weneckiej z XVI stulecia", trudno więc rozstrzygnąć, czy cytat jest autentyczny, czy sfingowany, nie jest to więc „prawdziwa” intertekstualność w tym sensie, co odwołanie do klasycznego utworu z pewnością znanego kompetentnemu czytelnikowi. Chwiejność sensów prymarnych sugeruje poszukiwanie sekundarnego, wspólnego połączonym mechanizmom - sądzę zaś, że jego wstępnym przybliżeniem może być alegoria, rozumiana tak, jak ją definiuje Paul de Man w Retoryce czasowości: ,jeśli w ogóle ma być alegoria, to jest czymś koniecznym, aby alegoryczny znak odnosił się do innego znaku, który go poprzedza. Znaczenie tworzone przez alegoryczny znak może zatem polegać tylko na pow tór z e ni u (w sensie Kierkegaardowskim) tego poprzedzającego znaku, z którym ów znak nigdy nie może być współczesny, jako że do istoty poprzedzającego znaku należy czysta uprzedniość" Zbieżności są oczywiste: Herling cytując powtarza opowieść, która ekfrastycznie powtarza płaskorzeźbę, a powtórzenia te dzieli dystans czasowy - opowieść jest szesnastowieczna, a sama ołtarz określa jako „stary”, niemniej - jak możemy dodać - też już zdystansowany względem źródłowych biblijnych zdarzeń, które przedstawia, nie z naoczności artysty tylko z kulturowej pamięci przecież. Co istotne, zbieżność między Grudzińskim a de Manem nie jest punktowa, lecz rozciąga się na inne elementy paralelnych struktur: de Man łączy alegorię z problematyką wyobcowanej romantycznej podmiotowości (czego synekdochą jest już przywołanie Kierkegaarda) w ten sposób, że bezpośrednio można ją skojarzyć z typowym losem bohaterów Herlinga-Grudzińskiego, w tym tych ze Skrzydet ottarza - do których, zgodnie zresztą z ustaloną już przez krytykę topiką lektury ${ }^{6}$, bez trudu dałoby się odnieść diagnozę, że: „Zeświecczona alegoria wczesnych romantyków zawiera tedy w sposób konieczny owo stadium negatywne, które u Rousseau jest momentem wyrzeczenia, u Wordswortha zaś momentem utraty «ja» w śmierci lub błędzie" - zarówno wyrzeczenie jak utrata ,ja” w śmierci ${ }^{8}$ lub (o)błędzie to figury natrętnie u Herlinga powracające, Rousseau i Wordswortha zastępują zaś w Wieży Xavier de Maistre i James Thomson.

Antycypujący de Mana o 10 lat diachroniczno-powtórzeniowy schemat alegorii nie ogranicza się u Herlinga do motta: przeciwnie, w obu członach dyptyku powraca wręcz obsesyjnie, jakby autorowi szczególnie zależało na quasi-teoretycznym

\footnotetext{
${ }^{5}$ Paul de Man, Retoryka czasowości, trans. Andrzej Sosnowski, in Alegoria, ed. Janina Abramowska (Gdańsk: słowo/obraz terytoria, 2003), 167-168.

${ }^{6}$ Cf. Joanna Jagodzińska-Kwiatkowska, Między świętością a szaleństwem. O postaciach $i$ sytuacjach liminalnych w opowiadaniach Gustawa Herlinga-Grudzińskiego (Bydgoszcz: Wydawnictwo UKW, 2013).

${ }^{7}$ Paul de Man, op. cit., 168.

${ }^{8}$ Jedna z klasycznych, zrytualizowanych metafor trądu w Wieży to „śmierć dla świata” (27).
} 
wyeksponowaniu go, a nie tylko zastosowaniu jako chwytu poetyki. W Wieży taki charakter ma już podstawowy paralelizm, ustanawiany zarówno przez bohatera jak i rozważającego jego los quasi-autorskiego narratora między samotnikiem $z$ domku na zboczu w latach II wojny światowej a trędowatym w wieży opisywanym przez de Maistre'a z perspektywy sabaudzkiego oficera w roku 1797 (a przy okazji między de Maistre'em jako owym oficerem a narratorem-Herlingiem jako alianckim oficerem w tużpowojennych Włoszech). Co charakterystyczne dla alegoryczności, paralelizm ten w znacznej mierze zapośredniczony jest przez materialność znaków: narrator znajduje w domku stare włoskie wydanie de Maistre’a oraz zeszyt z chaotycznymi „wypisami źródłowymi”, m.in. z Biblii i z Kierkegaarda. Znaki te wpisują się w obrazy alegoryczne także w bardziej tradycyjnym niż demanowski sensie, przy czym obecność sztychów Piranesiego uznać można za jawne przywołanie tej tradycji. Dla uchwycenia całości martwej natury potrzebny jest dłuższy cytat (w dalszej partii opowiadania bardzo podobnie skonstruowany jest opis celi trędowatego z wieży):

Mimo że duży i wygodny, pokój posiadał jedno tylko okno, które nie wystarczało, by rozproszyć panujący tu od świtu do zmierzchu półmrok i wysuszyć w kątach liszaje wilgoci. Nadgryzione przez korniki meble, krzesła i kozetka o wyliniałych obiciach ze skóry, gąszcz pajęczyny w kominku i na półce z książkami, lustro nad komodą w złoconej niegdyś ramie, które odbijało twarz jak przez smugę sadzy - wszystko to zdawało się doskonale harmonizować z czterema sztychami Piranesiego na ścianach. Kto widział bodaj raz w życiu jego sztychy, ten wie, że Piranesi gustował w ruinach i potrafił z nich wydobyć akcent ciała odpadającego od kości. W uczonej dysertacji o jego Więzieniach Aldous Huxley pisze, że wyrażają „,doskonałą bezcelowość”: „schody nie prowadzą donikąd, stropy nie podpierają niczego”.

Nad stolikiem w kącie, obok okna, wisiał jeszcze jeden, znacznie mniejszy sztych nieznanego autora i bez podpisu, przedstawiający na tle gór kwadratową wieżę otoczoną dość wysokim murem i wklinowaną pośrodku w sześcienny budynek z paroma zaledwie wąskimi otworami okiennymi. Nie piórko artysty nawet, lecz wyraz opuszczenia i niemej skargi - kamienna korona wieży wznosiła się ku czarnym kłębom chmur na niebie jak źle zaciśnięta pięść - czynił z tego sztychu martwy krajobraz, przy którym Piranesi stawał się jedynie bukolicznym poetą szczątków antyku. Na stoliku, między dwoma srebrnymi lichtarzami, leżała mała książeczka - tak brudna, wymięta i zatłuszczona kroplami stearyny, że odgadywało się w niej bez trudu ulubioną lekturę gospodarza w ciągu wielu lat. Był to Le Lépreux de la cité d'Aoste François-Xavier de Maistre'a w przekładzie włoskim i w wydaniu neapolitańskim z 1828 roku, ograniczonym do pięćdziesięciu numerowanych egzemplarzy. W oryginale angielskim tłumacz zachował motto z The Seasons. Winter Thomsona [8-9].

Jak zwraca uwagę de Man, w literaturze „wczesnoromantycznej” (którą u Herlinga $\mathrm{z}$ pewnym wyprzedzeniem reprezentuje poemat Thomsona) sens alegoryczny mają nie tylko takie w oczywisty sposób zsemiotyzowane martwe natury, jak powyższa, lecz także z pozoru realistyczne pejzaże - jak w Nowej Heloizie ${ }^{9}$. Podobnie jak sądzę należy u Grudzińskiego interpretować opis doliny Aosty, a zwłaszcza krajobraz izolowanej wyspy w drugim ogniwie dyptyku. Alegoryczna

\footnotetext{
${ }^{9}$ Paul de Man, op. cit., $157-167$.
} 
tekstualizacja obejmuje też - w obu opowiadaniach - ludzki los i tożsamość: „Nie zdołałem też nigdy ustalić okoliczności w jakich umarł Pier Bernardo Guasco, choć nie raz jeszcze po wojnie zaczepiałem w moich podróżach o Aostę. Natknąłem się jedynie na dwa warianty. [...] Ze wzruszeniem i uśmiechem rozpoznałem w obu tych wariantach niezrównaną zdolność ludu do ciągłego przerabiania starych legend: tak i oto w nowej postaci odżyły dwa podania dawnej Aosty - historia zagłodzenia księżniczki di Braganza w Bramafan i historia białej damy z Torre dello Spavento" (40), przy czym poza tymi wątpliwymi zakończeniami los trędowatego też jest powtórzeniem - losu Hioba, o którym u de Maistre'a czyta z Biblii skłoniony do tego pożegnalnym listem odnalezionym po śmierci siostry (20-21: ten motyw sam w sobie ustanawia alegoryczną temporalność), a narrator uzupełnia wspomnieniem przedstawiającej choroby Hioba płaskorzeźby z pobliskiej kolegiaty (34). Tak samo w Pietà dell'Isola: „Zawodne są analogie ludzkich losów. A przecież niepodobna oprzeć się uczuciu, że Sebastiano wszedł zrządzeniem nieznanej siły w koleinę przed wieloma setkami lat wyżłobioną dziejami nieszczęsnego twórcy Certosy i przez tyleż setek lat zasypywaną piaskiem toczącego się naprzód świata. Dla obu - choć z różnych przyczyn i w odmiennych okolicznościach - Certosa miała być koroną triumfalną; dla obu - też w różnych okolicznościach - stała się koroną cierniową" (62). Zakończenie głównego wątku przyjmuje postać żywego obrazu, w którym Immacolata z Sebastianem spontanicznie imitują kształt stojącej obok rzeźby: „nie wiadomo było, która $\mathrm{z}$ tych dwóch tkwiących obok siebie na ziemi rzeźb jest dziełem sieneńskiego mistrza, która zasługuje bardziej na miano Pietà dell'Isola! Lecz tylko jedna ożyła: Immacolata podniosła głowę, strąciła z pozłacanych raczej niż miedzianych włosów czarną koronkową chustkę, i ciszę rozdarł jej lament” (114), przy czym jak i w poprzednich przykładach nie chodzi o łatwe zrównanie losu wiernych $z$ losem ich boga, w symboliczne zestawienie wplata się bowiem alegoryczna seria artystycznych, w tym literackich, zapośredniczeń, całkowicie zbędnych z punktu widzenia tradycyjnie rozumianej fabuły, która jednak w opowiadaniach Grudzińskiego często jest tylko pretekstem dla figuralnej gry:

Nieznany autor Pietà dell'Isola musiał pilnie studiować rzeźby i obrazy swoich poprzedników i współczesnych na ten sam temat, zanim dotknął dłutem drzewa. Nie jest to dzieło oryginalne. W układzie Matki przypomina od pierwszego wejrzenia klasycyzującego Michała Anioła z Bazyliki Świętego Piotra, przed jego dramatycznymi formami z Pietà di Palestrina i Pietà del Duomo di Firenze. W układzie Chrystusa natomiast trzyma się nie tradycji ciała przegiętego miękko jak wstęga na wyciągniętych rękach, lecz starszej tradycji ciała zesztywniałego i naprężonego w idealnym niemal poziomie. Twarz Madonny, obramowana złotymi lokami wymykającymi się spod czarnej chustki, która opada Jej na ramiona, jest smutna, a jednak dziwnie uspokojona, jak w Pietà di San Giusto Perugina. Jej oczy i usta zdają się pocałunkiem przywierać do rozchylonych w bólu i pragnieniu warg Syna. Bierze ochota uwierzyć, że mistrz sieneński czytał Laudi trzynastowiecznego Jacopone da Todi i podczas pracy powtarzał sobie z nich często te dwa wersety, w których „Matka i Syn jedno mają pogrzebanie” i ,jedną objęci śmiercią, wspólne w bólu ukrzyżowanie" [56]. 
Serię powtórzeń i zapośredniczeń uzupełniają małe kopie Piety, które jeden z zakonników z pomocą Sebastiano robi dla turystów (96), oraz pocztówka z jej „popularną reprodukcją” (82), którą doktor Sacerdote widzi w pokoju księdza. Analogie wizualne, z zakresu historii i semiotyki sztuki, znajdują paralelę w onomastycznych - nieszczęsny Sebastiano i równie nieszczęśliwy Padre Rocca to ostentacyjna repersonifikacja dwóch charakterystycznych miejsc historycznych na wyspie: „w serca wstąpiła otucha na widok dwóch nowych kapliczek przydrożnych wzniesionych za radą biskupa Wyspy ku czci San Rocco i San Sebastiano, protektorów przeciw dżumie" (51), Immacolata zaś - czyli niepokalana - już swoim imieniem predestynowana jest do wcielenia się w rolę Matki Boskiej ${ }^{10}$, choć w sposób okrutnie ironiczny, skoro osią „,intrygi” jest właśnie „pokalanie” - gwałt, jakiego na parafiance dopuścił się ksiądz Rocca.

Przykładów podobnych do powyższych jest w dyptyku znacznie więcej - przywołałem tylko najważniejsze, ich drobniejsze echa multiplikują się jednak w tekście niemal w nieskończoność. Co istotne, praktyka tego rodzaju powtórzeń obejmuje także wątek autotematyczno-metafikcjonalny, gdy aluzyjnie wyobrażający autora narrator ${ }^{11}$ odnosi ją do własnych planów pisarskich: „Wielokrotnie próbowałem napisać opowieść o ostatnich sześciu latach życia mieszkańca Wieży w Aoście i zawsze odkładałem bezradnie pióro w połowie mniej więcej każdej nowej wersji. [...] De Maistre użył do swej opowieści motta z The Seasons. Winter osiemnastowiecznego Jamesa Thomsona; ja chciałem użyć do mojej dwuwiersza z City of Dreadful Night jego imiennika dziewiętnastowiecznego Jamesa Thomsona" (39-40). To demanowska alegoria w postaci klinicznie czystej: znaki jawnie powtarzają się, tyle że w sąsiednich stuleciach. Uznaję ten moment za szczególnie istotny, wzmacnia bowiem tezę, że - jak już sugerowałem - Herling nie tyle używa alegorii niejako przypadkowo, jako jednego z repertuaru dostępnych chwytów formalnych, z których równie dobrze mógłby wybrać coś innego, by wyrazić to, o co mu chodzi na poziomie zewnętrznej wobec formy treści, lecz że stara się zaprezentować sam mechanizm alegorii jako antropologicznie istotną treść - dokładnie tak samo, jak później de Man.

Dwaj autorzy Dzienników publikowanych w paryskiej „Kulturze” - Herling-Grudziński i Gombrowicz - zwykle są sobie przez krytyków przeciwstawiani ${ }^{12}$.

${ }^{10} \mathrm{O}$ tym oraz innych imionach i nazwiskach mówiących w Skrzydłach ottarza - cf. Gustaw Herling-Grudziński, Włodzimierz Bolecki, Rozmowy w Dragonei (Warszawa: Szpak, 1997), 168.

${ }^{11}$ Jedną z sygnatur Herlinga w tekście są odwołania do mitu kamiennej figury „pielgrzyma świętokrzyskiego", z którym urodzony w Kielcach autor utożsamia trędowatego - a poniekąd chyba i siebie. Wątek ten mocno akcentuje autointerpretacja Herlinga w Rozmowach w Dragonei, podkreślająca też związek opowiadania z osobistym doświadczeniem autora.

${ }^{12}$ Cf. Marian Bielecki, „Dlaczego Gustaw Herling-Grudziński bał się spotkać z Witoldem Gombrowiczem?", Teksty Drugie, no. 3 (2008). Podzielam dążenie autora do sproblematyzowania dystansu między tymi dwoma pisarzami, sądzę jednak, że przywoływana przeze mnie demanowska dekonstrukcja jest w tym celu bardziej pomocna niż np. koncepcja Rorty'ego jako jedna z wykorzystywanych 
Gdy jednak przeczytamy Skrzydta ottarza jako protodemanowski traktat o alegorycznej naturze rzeczywistości, okażą się bardzo bliskie pięć lat późniejszemu Kosmosowi jako studium relacji bohatera-narratora - podobnie jak u Herlinga syleptycznie półtożsamego z autorem - ze znakami, których wzajemne stosunki wydają się o wiele ważniejsze niż relacje ze słabo uchwytnymi lub w ogóle nieobecnymi signifiés ${ }^{13}$. Grudziński interpretowany tradycyjnie to $\mathrm{w}$ zasadzie chrześcijański egzystencjalista - co cytat z Kierkegaarda w tekście Wieży zdaje się potwierdzać. Najwybitniejsze literacko wcielenia podobnego światopoglądu w literaturze polskiej mamy w latach trzydziestych XX wieku - w Młynie nad Utrata Iwaszkiewicza i Ładzie serca Andrzejewskiego, z wcześniejszą poezją Lieberta w tle. Gdyby Herling po prostu kontynuował (względnie wskrzeszał) ten nurt, byłby w zasadzie tylko bardzo wyrafinowanym epigonem (można się wręcz doszukiwać motywicznych podobieństw między Wieża a opowiadaniem Iwaszkiewicza i Pieta a powieścią Andrzejewskiego). Sądzę jednak, że raczej gra z egzystencjalizmem poprzedników podobnie, jak współcześnie mu we Francji Lacan, Barthes, Foucault i Deleuze z egzystencjalizmem Sartre'a, albo ostrożniej - jak Gombrowicz, który w Dzienniku najpierw twierdzi, że był egzystencjalista jeszcze przed Sartre'em, by na etapie Kosmosu - mimo wstępnych oporów - zidentyfikować się właśnie ze strukturalistami i rozpoczynającymi już swoją drogę poststrukturalistami.

Opublikowanej 10 lat po Skrzydłach ołtarza Retoryki czasowości pisząc te dwa opowiadania Herling nie mógł znać, zbieżność zastosowanych przezeń rozwiązań z teorią jego belgijsko-amerykańskiego rówieśnika (obaj z rocznika 1919) jest więc zasadniczo tylko strukturalna. Można też jednak podejrzewać analogiczny efekt inspiracji podobnymi źródłami - oprócz oczywistych, ale dość odległych, jak estetyka klasycyzmu i romantyzmu, w grę wchodzi Źródto dramatu żałobnego $w$ Niemczech Waltera Benjamina, który dawne koncepcje alegorii i symbolu wpisuje w problematykę nowoczesności. Jawne nawiązania de Mana do Benjamina wydają się skromne, komentatorzy podkreślają jednak, że faktyczna zależność jest bardzo duża ${ }^{14}$. Herling-Grudziński o Benjaminie jako inspiracji nie wspomina, można jednak podejrzewać, że zetknął się z jego myślą, jeśli nie jako młody adept krytyki jeszcze przed wojną, to podczas pobytu

przez Bieleckiego (acz zarówno Rorty jak de Man piszą o ironii, choć w zasadniczo różnych sensach), podobnie zresztą niż jak pokrewna kategoria „postmodernizmu”, przywołana dla opisu intertekstualności (relacji „tekstów i ich przed-tekstów”) w Wieży przez Jerzego Paszka, co spotkało się z krytyką m.in. Arkadiusza Morawca w książce Poetyka opowiadań Gustawa Herlinga-Grudzińskiego (Kraków: Universitas, 2000), 48.

${ }^{13} \mathrm{Na}$ zbieżność rozważań o analogii w Piecie z mechaniką Kosmosu zwraca uwagę Bielecki, op. cit., 109.

${ }^{14}$ E.g. Kathleen Kerr-Koch, Romancing Fascism. Modernity and Allegory in Benjamin, de Man, Shelley (New York: Bloomsbury 2013), 83. Cf. Adam Lipszyc, Sprawiedliwość na końcu języka. Czytanie Waltera Benjamina (Kraków: Universitas, 2012), 185, 205, 217-218. 
w Monachium ${ }^{15}$. Przemawiałby za tym szczególnie duży zakres zbieżności między Skrzydtami ottarza (choć i szerzej twórczością pisarza) i rozprawą Benjamina. Oprócz omówionej już alegoryczności w obrazowaniu byłoby to powiązanie alegorii z melancholią ${ }^{16}$ (człowiek z domku-trumny w Wieży i Padre Rocca w Piecie to ostentacyjnie typowi melancholicy) ${ }^{17}$, ujęcie centralnego bohatera jako „męczennika", acz niewolnego od własnej tragicznej winy, skupiające się raczej na patosie cierpienia niż na akcji w sensie arystotelesowskim ${ }^{18}$ (przykłady trędowatego z Aosty i Sebastiana), uznanie ruin za motyw szczególnie dla alegorii charakterystyczny - a zarówno w Wieży, jak zwłaszcza w Pietà dell'Isola Herling nieraz wzmiankuje ruiny rzymskie i średniowieczne, w większości zupełnie nieistotne dla fabuły ${ }^{19}$; wychodząc poza samo Źródło, do repertuaru analogii dodać by można zainteresowanie ,aurą” dawnych dzieł sztuki skonfrontowaną $\mathrm{z}$ możliwością ich reprodukcji technicznej ${ }^{20}$.

Zarówno Benjamin jak i de Man za klasykami przeciwstawiają alegorię symbolowi, odwracając jednak wartościowanie - dla nich to alegoria jest antropologicznie prawdziwsza, symbol w swej rzekomej bezpośredniości okazuje się zaś pozorem, złudzeniem bądź samooszustwem. Jak to wygląda u Herlinga? Ryszard Nycz, wpisując Grudzińskiego w poetykę epifanii, zdaje się ją zrównywać z tradycyjnym rozumieniem symbolu jako momentalnego, quasi-zmysłowego objawienia ponadzmysłowej rzeczywistości - nie używa wprawdzie samego słowa „symbol”, przywoływane przezeń w roli quasi-terminów cytaty z Herlinga, mówiące o „odpryskach” czy „odłamkach”21, zdają się jednak odwoływać do tego samego schematu kognitywnego - symbolon to bowiem pierwotnie fragment czegoś rozłamanego,

${ }^{15}$ Kilka drobnych wzmianek o Benjaminie jest w Dzienniku pisanym noca, nie wiążą się jednak $\mathrm{z}$ analizowaną przeze mnie problematyką (poza odwołaniami do Kafki, który jest autorem motta Piety), hipoteza o ewentualnym bezpośrednim wpływie Benjamina musiałaby zatem zakładać, że został on wyparty do pisarskiej nieświadomości (zgodnie z modelem, który za Freudem proponuje Harold Bloom), trudno bowiem sobie wyobrazić, żeby przywołujący w autokomentarzach mnóstwo źródeł inspiracji Herling tę akurat z premedytacją ukrywał.

${ }^{16}$ Cf. Walter Benjamin, Źródło dramatu żałobnego w Niemczech, trans. Andrzej Kopacki (Warszawa: Sic!, 2013), 175-204.

${ }^{17}$ Melancholików Grudzińskiego z myślą Benjamina zestawia Jagodzińska-Kwiatkowska, op. cit., 371-374, nie sięga jednak po kategorię alegorii.

${ }^{18}$ Walter Benjamin, op. cit., $74-83$.

${ }^{19}$ Ibidem, 234-245.

${ }^{20}$ Vide Ryszard K. Przybylski, „Pozostając w aurze dzieła sztuki”, in „Cienie wielkich artystów”, 25-29. Z tego zakresu w Skrzydłach ottarza pojawiają się np. wątki reprodukcji Piety, sztychów Piranesiego itp. Zgodnie $\mathrm{z}$ definicją de Mana reprodukcja jest zresztą formą alegorii jako powtórzenia przeszłego znaku. Do Benjamina w wielu miejscach nawiązuje też Feliks Tomaszewski w książce Drogi $i$,stacje wygnania”. Podróże i powroty Gustawa Herlinga-Grudzińskiego (Gdańsk: Wydawnictwo UG, 2006) - tertium comparationis stanowi tam przede wszystkim figura flâneura, pojawia się też jednak wątek ruin, choć bez związku z alegorią.

${ }^{21}$ Ryszard Nycz, Literatura jako trop rzeczywistości. Poetyka epifanii w nowoczesnej literaturze polskiej (Kraków: Universitas, 2001), 210. 
który dopasowany do drugiej części pozwala zidentyfikować jej posiadacza. Czy skoro Wieża ma odpowiadać Złożeniu do Grobu, a Pietà - Zmartwychwstaniu, tylko pierwsza jest konsekwentnie alegoryczna, druga zaś przekracza alegorię ku symbolowi? Tak i nie zarazem: jednoznaczny symbol pojawia się na zakończenie dyptyku, zostaje jednak przez narratora explicite zakwestionowany:

I dopiero wtedy odepchnięto trzech zakonników i poniesiono w triumfie statuę do kościoła na Placyku, kładąc kres wiekowej niechęci Wyspy do Certosy. Jeszcze tego samego wieczoru obiegła Wyspę, podawana z ust do ust, wiadomość że dokładnie w momencie gdy zmartwychwstał Sebastiano (gdyż takiego zwrotu używano na określenie epilogu procesji Pietà dell'Isola z 19 września 1950 roku: quando è risorto il nostro Sebastiano), w katedrze neapolitańskiej upłynniła się zakrzepła krew Świętego Męczennika z Pozzuoli. Nie było to ścisłe; w zapisie katedralnym $\mathrm{z}$ tego roku widnieje godzina Miracolo di San Gennaro wcześniejsza nawet od wyjścia orszaku z Certosy. Ale po dziś dzień nikt i nic nie jest w stanie zachwiać w oczach mieszkańców Wyspy tej rzekomej cudownej koincydencji. Południe kocha się w cudach jak ludzie samotni w snach i nie pozwoli ująć z nich ani jednej ozdoby opromieniającej je dodatkowym blaskiem, choćby nie wytrzymywała próby najprostszej kontroli faktów. W cudach bowiem, w tęsknocie do nich i oczekiwaniu na nie, odnajduje - właśnie jak człowiek samotny w snach - nadzieję że można uciec rzeczywistości, jeśli jest zbyt okrutna [116-117].

Przestrzenna synchroniczność to dla de Mana definicyjna cecha symbolu ${ }^{22}$ - w opozycji do czasowej alegorii; Certosa jednoczy się z Wyspa po wiekach mentalnego (i zarazem temporalnie alegorycznego) rozdzielenia - jak dwie połówki symbolu w jego tradycyjnym rozumieniu: „Nigdy, jak w owej drugiej połowie maja 1950 roku, nie zadzierzgnęły się takie nici serdecznej zażyłości między Wyspą a Certosą, precz odpędzając cienie dawnej i nowszej przeszłości" (97). Ale dla narratora to życzeniowe złudzenie, znów jak symbol w ujęciu de Mana: „symboliczny styl nigdy nie zazna spokoju - ponieważ jest zasłoną zarzuconą na światło, którego nikt nie chce już widzieć na oczy, nigdy nie zyska zupełnej czystości poetyckiego sumienia"23. Benjamin daje szansę na dialektyczne zjednoczenie obu perspektyw: poetycki symbol romantyczny to owszem oszustwo, które alegoria słusznie demaskuje, gdzieś w tle pozostaje jednak enigmatyczny symbol „prawdziwy”, teologiczny, autentycznie uobecniający transcendencję ${ }^{24}$. Uproszczone ujęcie Herlinga jako pisarza religijnego kazałoby przypisywać mu dążenie do tej drugiej właśnie, autentycznej symboliczności. Jednak cud na Wyspie jest symbolem szczerze religijnym i metafizycznie fałszywym zarazem - prawdziwe jest tylko cierpienie, ale ono pozostaje alegorycznym patosem rozdarcia. Jeśli więc religijność, to w domenie „Boga ukrytego”, a może i „śmierci Boga” - albo mistycznej „nocy ciemnej”" ${ }^{25}$. W przypadku Grudzińskiego narzuca się też

\footnotetext{
${ }^{22}$ Paul de Man, op. cit., 167.

${ }^{23}$ Ibidem, 169.

${ }^{24}$ Cf. Adam Lipszyc, op. cit., 203.

${ }^{25} \mathrm{O}$ elementach mistyki u Herlinga - cf. Joanna Bielska-Krawczyk, Świat w sasiedztwie zaświatów (Kraków: Universitas, 2011), 275-293.
} 
jednak dodatkowe pytanie: o k tór ą mianowicie religię chodzi? Chrześcijaństwo w wersji katolickiej, z którego pochodzi motywika opowiadań, a które przyszły ich autor przyjął jako człowiek już dorosły, czy judaizm, z którego wyrósł? Podobną ambiwalencję mamy zresztą u Benjamina: imaginarium, które analizuje w Źródle, ukształtowało się w chrześcijańskiej kulturze baroku, samego autora zwykło się jednak traktować jako nieortodoksyjnego przedstawiciela tradycji żydowskiej.

Choć symboliką katolicką Skrzydła ołtarza są wręcz barokowo przeładowane, nie brak w nich pobocznego wątku żydowskiego - w czasie faszystowskich prześladowań na Wyspie ukrywają się (skutecznie) włoscy Żydzi, w tym przyjaciel Padre Rocca - Doktor Sacerdote, szczęśliwszy jako uciekinier niż w podobnych okolicznościach Walter Benjamin ${ }^{26}$; to chyba znów nazwisko mówiące, „sacerdote” znaczy bowiem 'kapłan' (jakby tłumaczenie hebrajskiego kohen, częstego jako nazwisko), wprowadza więc kwestię porównania religii mimo tego, że temat judaizmu jako wyznania jawnie się nie pojawia ${ }^{27}$. W kontekście późniejszych opowiadań Herlinga sensu takiego nabiera także finałowy motyw eucharystycznego cudu w Neapolu: jak podkreśla Joanna Tokarska-Bakir, zgodnie z antysemicką tradycją w Drugim przyjściu (opublikowanym rok po Skrzydłach ottarza) i prawie 40 lat późniejszej Legendzie o nawróconym pustelniku topos cudów eucharystycznych wiąże się z kwestią prześladowania i przymusowego nawracania Żydów ${ }^{28}$. Badaczka wpisuje ten motyw w dyskusję o „zdradzonej” żydowskości Grudzińskiego, odczytując jego opowiadania jako afirmatywne wobec tradycji katolickiej i przez to w tym kontekście jakby usprawiedliwiające jej antysemityzm. Ja tymczasem skłonny byłbym odczytywać te opowiadania raczej jako ironiczne - albo, zważywszy konstytutywne dla ich motywiki obrazy krwi i tortur - jako „sarkastyczne” w quasi-słowotwórczym sensie sarkazmu jako „szarpania mięsa" (analogicznie sarkastyczne jest też opowiadanie $C u d$, alegorycznie odwołujące się do neapolitańskiej legendy bez podnoszenia kwestii żydowskiej).

Problem w tym, że nie jest to ironia w prostym sensie antyfrazy, która jawnemu znaczeniu przedmiotowemu symetrycznie przeciwstawiałaby odwrotną intencję podmiotowego ironisty - raczej radykalna ironia w sensie (tak jak w przypadku alegorii) zbliżonym do tego, który wypracował Paul de Man, tak iż na samej powierzchni tekstu nie możemy rozstrzygnąć, jakie jest jego „literalne” znaczenie, widzimy tylko dynamiczną grę - albo i walkę - tropicznych sił, z którymi powiązane są konkurencyjne tożsamości - żydowska i katolicka, ale chyba też

${ }^{26}$ Który skądinąd znaczną część rozprawy o dramacie żałobnym napisał na Capri, stanowiącej pierwowzór Wyspy Herlinga (vide J. Bielska-Krawczyk, Świat w sasiedztwie zaświatów, 255-270).

${ }^{27}$ G. Herling-Grudziński, W. Bolecki, op. cit., 168. Ibidem, 164 - o religijności Kafki niesprowadzalnej ani do judaizmu, ani do chrześcijaństwa.

${ }^{28}$ Joanna Tokarska-Bakir, „Gustaw Herling-Grudziński i legenda o krwi, czyli czy istnieje obowiązek bycia pisarzem żydowskim”, Studia Litteraria et Historica, no. 3-4 (2015). 
„nowoczesna”, egzystencjalno-ateistyczna, wręcz w stylu Camusa i Sartre’a, przy czym wątpliwe, żeby jakieś autorskie „centrum dowodzenia” nad tą dynamiką podmiotowo panowało, narzucając jej jednolitą intencję $e^{29}$. Można zaryzykować twierdzenie, że w systemie tropów ironią taką zarówno de Man jak Herling-Grudziński zastępują „prawdziwą” religijną symboliczność, o której jeszcze marzył Benjamin - benjaminowskiej serii 'symbol religijny - symbol romantyczny - alegoria' przeciwstawiają więc własną 'symbol romantyczny - alegoria - ironia'30. Religijny symbol miałby łączyć świat z zaświatową transcendencją Boga, ironia przeciwnie - oddziela od świata podmiot, czyniąc go ludzką quasi-transcendencją: „Dédoublement oznacza zatem taką czynność świadomości, w której człowiek odróżnia się od nieludzkiego świata" ${ }^{31}$. Krytyka dawno rozpoznała analogiczne oddzielenie bohaterów Herlinga od świata - zakładając wszakże, że wstępne odróżnienie od doczesności wiedzie ich dalej ku transcendencji religijnej, której szukał Benjamin, co z perspektywy de Mana wydaje się wątpliwe: „Język ironiczny rozkłada podmiot na «ja» empiryczne, które żyje w stanie nieautentyczności, oraz na inne «ja», które istnieje tylko w postaci języka zatwierdzającego wiedzę o tejże nieautentyczności. Co jednak wcale nie zmienia go w jakiś język autentyczny, gdyż znać nieautentyczność nie jest tym samym, co autentycznym być" 32 .

\author{
ALLEGORY IN THE "PIETA DELL'ISOLA": \\ HERLING-GRUDZIŃSKI, BENJAMIN, DE MAN
}

Sum mary

The article juxtaposes the diptych of short stories by Gustaw Herling-Grudziński, The Tower and Pieta dell'Isola, with the theories of allegory developed by Paul de Man in The Rhetoric of Temporality as well as by Walter Benjamin in The Origin of German Tragic Drama. The analyses reveal several points of convergence in the structure and motives present in the works by Grudziński and in the texts by these critics. In the case of Benjamin, this would suggest his influence on Herling, whereas in the case of de Man, it reveals a parallelism of thoughts of the two contemporaries working with different genres and different interpretative communities, yet developing very similar conceptions of the text as well as of the man.

${ }^{29}$ Aby w pełni uświadomić sobie tę dekonstrukcyjną moc w Skrzydłach ołtarza czy zwłaszcza w Drugim przyjściu, warto porównać je z nieco wcześniejszym Księciem niezłomnym (1956) - opowiadaniem, nad którym autor najwyraźniej sprawuje pełną podmiotową kontrolę: jako ironiczny w konwencjonalnym, nie demanowskim sensie moralista, satyrycznie osądzający współczesną politykę i niepozostawiający żadnych niejasności co do własnych intencji. W efekcie jednak zamiast dojrzałego opowiadania, jak dwa lata później w Wieży (1958), otrzymujemy na początek nudnawe wypracowanie na założony temat, mimo że zestaw motywów i chwytów literackich jest już z grubsza ten sam, co w utworach późniejszych.

${ }^{30}$ Cf. Paul de Man, op. cit., 169-177.

${ }^{31}$ Ibidem, 175.

${ }^{32}$ Ibidem, 177. 